KATSAUS

\title{
IPR-aineistojen mahdollisuuksia, replikointitarpeita ja teknisiä haasteita
}

\author{
Jussi Heikkilä \\ Jyväskylän yliopiston kauppakorkeakoulu \\ jussi.heikkila@jyu.fi \\ https://orcid.org/0000-0002-5122-7956
}

Tässä artikkelissa tehdään katsaus aineettomien oikeuksien eli IPR- (intellectual property rights) aineistoihin erityisesti suomalaisesta ja eurooppalaisesta näkökulmasta. Keskityn patentti-, hyödyllisyysmalli-, tavaramerkki- ja mallioikeusaineistoihin eli teollisoikeuksiin jättäen tekijänoikeudet tarkastelun ulkopuolelle. Digitalisaation myötä rekisteriaineistojen laatu ja saatavuus ovat jatkuvasti lisääntyneet ja IPR-järjestelmien toiminnan tutkimus sekä hypoteesien empiirinen testaus ovat tulleet mahdolliseksi ennennäkemättömällä tavalla. Eräitä mielenkiintoisia aiheita, joiden tutkimuksen yhä laadukkaammat IPR-aineistot mahdollistavat ovat 1) kokonaisvaltaisempi IPR-analyysi, joka patenttien ohella hyödyntää tavaramerkki-, mallioikeus- ja hyödyllisyysmalliaineistoja, 2) Euroopan integraation ja Kiinan roolin kasvun vaikutusten analyysi IPRkontekstissa ja 3) digitalisaation ja tekoälyn vaikutusten arviointi sekä uudet sovelluskohteet IPR-alalla. Lisäksi aiempien tutkimusten toistaminen eli replikointi nykyisillä aiempaa kattavammilla ja laadukkaammilla rekisteriaineistoilla olisi tärkeää, koska digitalisaatio ja globalisaatio ovat 200o-luvulla muuttaneet IPR-toimintaympäristöä nopealla tahdilla.

Asiasanat: patentit, hyödyllisyysmallit, tavaramerkit, mallioikeus, immateriaalioikeus 


\section{Johdanto}

Patentit, hyödyllisyysmallit, tavaramerkit ja mallioikeudet ovat aineettomia oikeuksia ja kielto-oikeuksia. Patentin tai hyödyllisyysmallin haltijalla on oikeus kieltää muita hyödyntämästä kaupallisesti patentti- tai hyödyllisyysmallidokumentissa kuvattua teknistä keksintöä. Vastaavasti tavaramerkin haltija voi suojatulla tavaramerkillä erotella omat tuotteet tai palvelut kilpailijoista ja suojata brändiä. Mallioikeus suojaa tuotteiden ulkomuotoa kopioijilta: sen haltija voi kieltää muita jäljittelemästä mallioikeudella suojattujen tuotteiden muotoilua.

Patenttitietokannat tarjoavat ikkunan teknologiseen kehitykseen - sekä menestyneisiin että vähemmän toimiviin teknisiin keksintöihin. Patentin haltijan on saamaansa määräaikaista yksinoikeutta (kielto-oikeutta) vastaan kuvattava patenttidokumentissa keksintönsä siten, että alan ammattilainen kykenee sen kuvauksen pohjalta toteuttamaan. Patenttijärjestelmän kaksi keskeistä tehtävää ovat siis 1) luoda kannustimia innovaatiotoimintaan ja 2) levittää teknistä tietoa patenttitietokantojen kautta. Mallioikeustietokannat toimivat vastaavalla tavalla muotoilun osalta ja tavaramerkkitietokannat brändien osalta. IPR-dokumenteista löytää paljon hyödyllistä tietoa ja patentti- ja muuta IPR-informaatiota voi hyödyntää muun muassa kilpailijaseurannassa sekä tutkimus- ja kehitystoiminnan suunnittelussa.

Informaatiotutkimuksen näkökulmasta patentti- ja muiden IPR-dokumenttien sisältämä bibliografinen informaatio tarjoaa erityisen rikkaan tutkimusaineiston moniin tutkimuskysymyksiin vastaamiseen. Millä aloilla teknistä tietoa syntyy patenttitietokantoihin? Ketkä tuottavat tätä teknistä tietoa? Ketkä hyödyntävät tätä teknistä tietoa? Kuinka nykyiset keksinnöt rakentuvat aiempien päälle? Bibliometriikan ja skientometriikan menetelmät, joita sovelletaan tieteellisten julkaisujen analyysissä, soveltuvat yhtä lailla myös patentti- ja IPR-informaation tutkimukseen.

Ensimmäinen patenttijärjestelmä luotiin Venetsiassa vuonna 1474 (ks. esim. Comino ym. 2020). Paljon on ehtinyt tapahtua viimeisten noin 550 vuoden aikana, mutta itse ihmisten elintasoa kohottava teknologinen kehitys on kiihtynyt vasta viimeisen parin sadan vuoden aikana (ks. esim. Roser 2013). Ensimmäinen "suomalainen patentti" myönnettiin Lars G. Ståhlen puhallinkoneelle 29. kesäkuuta vuonna 1842. ${ }^{1}$ Vasta 1900-luvun loppupuolella digitalisaation myötä koneluettavien aineistojen laatu ja saatavuus ovat kasvaneet merkittävästi. Näin on tapahtunut myös aineetto-

1

https://www.prh.fi/fi/tietoa_prhsta/organisaatio_ja_tehtavat/historia/ ensimmainen_suomalainen_patentti.html (Viitattu 16.8.2021) 
mien oikeuksien eli IPR-aineistojen osalta. Digitalisaatio on demokratisoinut IPR-rekisterien saatavuutta ja käyttömahdollisuuksia. Patenttikirjastot ovat siirtyneet fyysisistä kirjastoista ja paperisista dokumenteista verkkoon kaikkien saataville. ${ }^{2}$

Samanaikaisesti aineettomien oikeuksien hakemusmäärät ovat kasvaneet valtavasti kuten Kuvio 1 havainnollistaa. Vuonna 1994 solmittiin kansainvälinen immateriaalioikeuksia koskeva Maailman kauppajärjestön WTO:n TRIPS-sopimus ("Agreement on Trade-Related Aspects of Intellectual Property Rights”), joka yhdenmukaisti jossain määrin maailman IPR-järjestelmiä. Pelkästään 2000-luvun ensimmäisten kahden vuosikymmenen aikana, 2000-2019, IPR-tietokannat ovat paisuneet miljoonilla dokumenteilla.

Maailman henkisen omaisuuden järjestön WIPO:n mukaan yksistään vuonna 2019 tehtiin noin 3,2 miljoonaa patenttihakemusta, 2,3 hyödyllisyysmallihakemusta, 15,2 miljoonaa tavaramerkkihakemusta ja 1,4 miljoonaa mallioikeushakemusta (WIPO 2021). Kiinan osuus IPR-hakemusten kasvusta on ollut erityisen merkittävä erityisesti sen liityttyä WTO:hon joulukuussa 2001: WIPO:n (2021) mukaan Kiinassa haettiin vuonna 2019 eniten kaikkia edellä mainittuja suojamuotoja ja Kiinan patenttivirastolla jätettyjen hakemusten osuus kaikista maailman hakemuksista oli 43,4 \% patenttihakemuksista, 96,9 \% hyödyllisyysmallihakemuksista, 51,7 \% tavaramerkeistä ja 52,3 \% mallioikeuksista.

2 Tämä on ollut myös paloturvallisuuden kannalta hyvä asia. Vuonna 1933 "Helsingin kaupungin palopäällikkö oli todennut viraston [PRH:n] tilat Ratakatu 12:ssa paloturvallisuuden kannalta käyttötarkoitukseensa sopimattomiksi. Koko patenttien uutuustutkimusaineisto olisi palon sattuessa menetetty kerralla, joten kyseessä oli patentinhaltijoiden oikeusturva" (Laisi 2009, s. 34). 

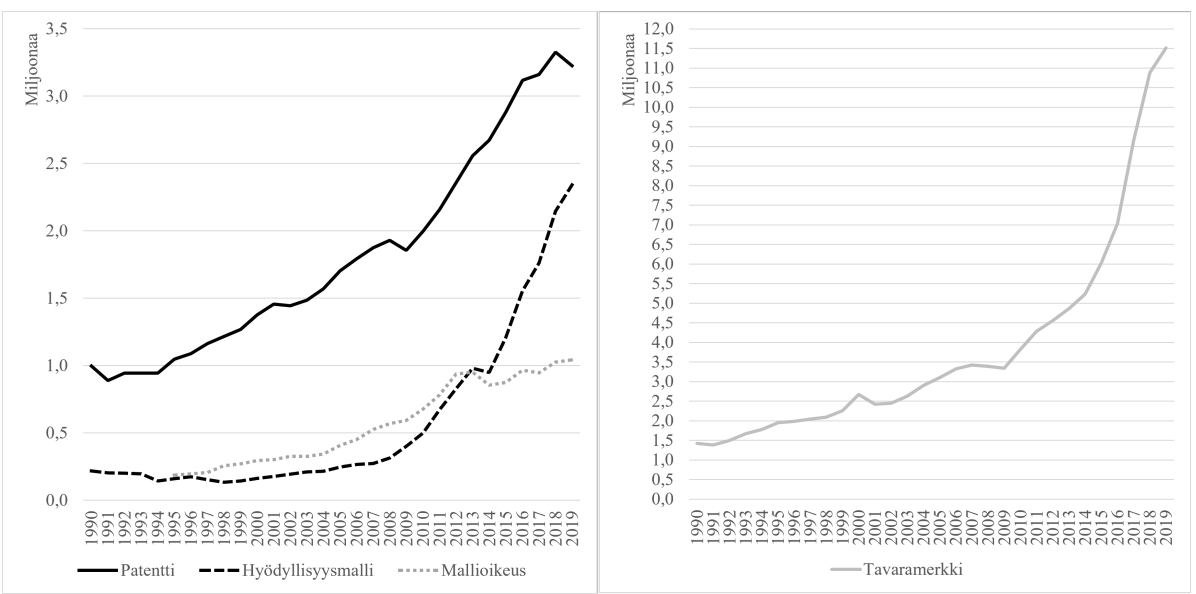

Kuvio 1. IPR-hakemusmäärien globaaleja trendejä.

Lähde: WIPO IP Statistics Data Center (päivitetty 2021, tiedot haettu 16.8.2021). Hakemusmäärät sisältävät suorat hakemukset patenttivirastoille sekä WIPO:lle tehdyt hakemukset.

Pitkällä aikavälillä innovaatiot ovat tuottavuuden kasvun ja siten talouskasvun ja ihmisten elintason nousun taustalla. Aineettomien oikeuksien instituutiot luovat tutkimus-, kehitys- ja innovaatiotoimintaan kannustimia, minkä vuoksi niiden kehittämisen tueksi tarvitaan tutkimustietoa. Aihe on erityisen ajankohtainen Suomen kontekstissa, sillä Suomessa on käynnissä IPR-strategian päivitys (Salminen ym. 2021; Oker-Blom 2021). Aineistojen parempi saatavuus ja kasvanut laatu mahdollistavat IPR-aineistojen tehokkaamman käytön päätöksenteon tukena.

200o-luvulla eri maiden kansalliset patenttiviranomaiset ovat edistäneet aineistojen saatavuutta ja perustaneet ekonomistitiimejä analysoimaan näitä aineistoja. ${ }^{3}$ Erilaiset empiiriset analyysit IPR-järjestelmiä koskevista politiikkamuutoksista ja reformeista ovat tämän vuoksi aiempaa helpommin toteutettavissa. Aiempien tutkimusten replikointi eli toistaminen on tärkeää, koska aineettomien oikeuksien ympäristö muuttuu ajassa vuorovaikutuksessa muiden instituutioiden ja innovaatiopolitiikan instrumenttien (Bloom ym.

3 Esim. Euroopan patenttivirasto, EPO Chief Economist Unit: https://www.epo.org/ about-us/services-and-activities/chief-economist.html; Yhdysvallat, USPTO, Office of the Chief Economist: https://www.uspto.gov/about-us/organizational-offices/ office-policy-and-international-affairs/office-chief-economist; WIPO, The Department for Economics and Data Analytics: https://www.wipo.int/about-wipo/en/ activities_by_unit/index.jsp?id=48; IP Australia: https://www.ipaustralia.gov.au/ about-us/research-and-data/office-chief-economist (Viitattu 16.8.2021) 
2019) kanssa. Teknologinen kehitys, globalisaatio ja Euroopan integraatio vaikuttavat myös aineettomien oikeuksien toimintaympäristöön jatkuvasti.

Artikkeli on organisoitu seuraavasti. Osiossa 2 esittelen lyhyesti tarkastelun kohteena olevat suojamuodot sekä niihin liittyvät instituutiot. Osiossa 3 listaan aihepiirin tutkimuksissa hyödynnettäviä aineistoja. Viimeisessä osiossa 4 ehdotan eräitä jatkotutkimusaiheita ja nostan esiin aihepiirin tutkimukseen liittyviä teknisiä haasteita.

\section{Suojamuodot, instituutiot ja rekisterit}

\section{Teollisoikeudet}

Rajaudun keskeisiin teollisoikeuksiin eli patentteihin, hyödyllisyysmalleihin, tavaramerkkeihin ja mallioikeuksiin. Tekijänoikeuksia ei tässä artikkelissa tarkastella, koska tekijänoikeuksista ei ole vastaavia rekistereitä kuin teollisoikeuksista. Näiden lisäksi löytyy vielä muitakin suojamuotoja (mm. kasvinjalostajan suoja ja maantieteellinen merkintä), jotka jäävät tämän tarkastelun ulkopuolelle. On myös syytä mainita, että tämän artikkelin näkökulmapainotus on informaatiotutkimuksessa ja taloustieteessä oikeudellisen näkökulman sijaan. Suosittelen lukijaa perehtymään esimerkiksi Haarmannin Immateriaalioikeus-teokseen (2014), jos lukija on kiinnostunut kattavammasta perehdytyksestä aineettomiin oikeuksiin. Esittelen seuraavaksi suojamuodot pääpiirteittäin. ${ }^{4}$

Patentti on suojamuoto teknisille keksinnöille. Patentti voidaan myöntää tekniselle keksinnölle, joka täyttää patentoitavuuden kriteerit (uutuus, keksinnöllisyys ja teollinen käyttökelpoisuus), maksimissaan 20 vuodeksi hakemispäivästä. Patenttitietokannoissa on yli 130 miljoonaa patenttidokumenttia ${ }^{5}$ ja vuonna 2020 haettiin 3,2 miljoonaa patenttia (WIPO 2021). On syytä pitää mielessä, että patentit kuten muutkin teollisoikeudet ovat kansallisesti säädettyjä yksinoikeuksia. Yleisellä tasolla voidaan sanoa, että patenttiperhe koostuu samaa keksintöä suojaavista eri maissa haetuista patenteista, mutta patenttiperheelle on olemassa vaihtoehtoisia tarkempia määritelmiä (ks. Martínez 2011; Kang \& Tarasconi 2016).

Hyödyllisyysmalli, johon toisinaan viitataan "pikkupatenttina", on patentin tavoin suojamuoto teknisille keksinnöille. Kaikissa maissa ei ole

$4 \quad$ Patentti- ja rekisterihallituksen (PRH) sivulta löytyy myös yleiskuvaukset. https://www. prh.fi/ (Viitattu 16.8.2021)

5 https://www.epo.org/searching-for-patents/technical/espacenet.html (Viitattu 16.8. 2021) 
hyödyllisyysmallijärjestelmää ja niissä maissa, joissa on hyödyllisyysmallijärjestelmä, niiden ominaisuudet poikkeavat toisista merkittävästi maiden välillä (ks. esim. Heikkilä 2018). Suomessa hyödyllisyysmallin keksinnöllisyysvaatimus on alempi kuin patentilla kuten myös suoja-aika, joka on maksimissaan 10 vuotta. Tutkimusten ja selvitysten mukaan hyödyllisyysmalleja käytetään tyypillisesti suojattujen keksintöjen kansalliseen suojaamiseen eli ne ovat verraten harvoin osa kansainvälistä patenttiperhettä (Heikkilä \& Verba 2018). Tutkimuskirjallisuudessa hyödyllisyysmallit ovat jääneet suhteellisen vähälle huomiolle mahdollisesti muun muassa siksi, että Yhdysvalloissa ei ole kyseistä järjestelmää käytössä.

Tavaramerkki on tunnusmerkki, joka erottaa tietyn yrityksen tavarat ja palvelut muiden vastaavista, eli toimii erottamisvälineenä markkinoilla ja elinkeinotoiminnassa. Yksinoikeus tavaramerkkiin antaa tavaramerkin haltijalle oikeuden kieltää muita käyttämästä samaa tai samankaltaista merkkiä samojen tai samankaltaisten tavaroiden tai palveluiden yhteydessä. Tämän vuoksi tavaramerkin hankkiminen on tehokas tapa saada suojaa omalle brändille. Tavaramerkin saa haltuunsa rekisteröimällä tai vakiinnuttamalla. Tavaramerkki vakiinnutetaan käyttämällä merkkiä elinkeinotoiminnassa, kunnes merkki on yleisesti tunnettu tiettyjen tavaroiden tai palveluiden yhteydessä. Tavaramerkkejä on patenttien ohella hyödynnetty innovaatiotoiminnan indikaattoreina (Flikkema ym. 2014; Castaldi 2020).

Mallioikeus suojaa tuotteen ulkomuotoa ja se on teollisen muotoilun merkittävin oikeudellinen suojakeino. Mallioikeuksia on alettu tutkia kasvavassa määrin (ks. esim. Heikkilä ja Peltoniemi 2019) ja aivan viime aikoina esimerkiksi EU:n tasolla (Euroopan komissio, 2020) sekä Australiassa (Kollmann ym. 2020) on toteutettu mallioikeusjärjestelmien arviointeja.

\section{Alueelliset instituutiot ja rekisterit}

Aineettomat oikeudet ovat alueellisesti rajattuja yksinoikeuksia, jotka nojaavat kansalliseen lainsäädäntöön ja kansainvälisiin sopimuksiin. Joka maassa on erinäinen joukko kansallisia aineettomiin oikeuksiin liittyviä lakeja, ja maat ovat vaihtelevassa määrin jäseninä ja allekirjoittajina erinäisessä joukossa kansainvälisiä aineettomiin oikeuksiin liittyviä sopimuksia. Lisäksi EU:n jäsenmaihin kuten Suomeen kohdistuu EU:n lainsäädäntö ja eurooppalaiset instituutiot. Maakohtaisiin IPR-lainsäädäntöihin ja kansainvälisiin sopimuksiin voi tutustua mm. avoimessa WIPO Lex -tietokannassa, joka tarjoaa mahdollisuuden hakea tietoa ajantasaisista ja aiemmista IPR-laeista, 
kansainvälisistä sopimuksista sekä tuomioistuinten päätöksistä (yht. 49000 dokumenttia). ${ }^{6}$

Taulukossa 1 on havainnollistettu suomalaisesta näkökulmasta lainsäädännön ja sopimusten eri alueellisia tasoja, niihin liittyviä organisaatioita ja valikoituja tietokantoja. Suomessa patentteja myöntää Patentti- ja rekisterihallitus, PRH. Euroopan patenttivirasto EPO myöntää patentteja, jotka voidaan saattaa voimaan hakijan valitsemissa EPO:n jäsenmaissa (ml. Suomessa). Lisäksi WIPO:n "Patent Cooperation Treaty" eli PCT-järjestelmän kautta voi tehdä kansainvälisen patenttihakemuksen. Instituutiot eivät ole tämän katsausartikkelin fokus, mutta aina IPR-aineistoja hyödyntäessä on tärkeää pitää mielessä oikeuksien alueellinen näkökulma ja mahdolliset "päällekkäiset" instituutiot eli vaihtoehtoiset kanavat aineettomien oikeuksien hakemiselle ja suojaukselle. Voi kuitenkin todeta, että globalisaation (ml. TRIPS) ja Euroopan integraation sekä EU:n laajenemisen myötä kansainvälisten instituutioiden merkitys näyttää suomalaisesta näkökulmasta kasvaneen kansallisten instituutioiden kustannuksella. IPR-instituutioiden evoluutio tarjoaa mielenkiintoisia tutkimusaiheita.

Taulukko. 1 Instituutioita ja tiedonhakupalveluja eri alueellisilla tasoilla.

\begin{tabular}{|l|l|l|l|l|}
\hline & Patentti & $\begin{array}{l}\text { Hyödyllisyys- } \\
\text { malli }\end{array}$ & Mallioikeus & Tavaramerkki \\
\hline $\begin{array}{l}\text { Lain- } \\
\text { säädäntöä tai } \\
\text { kansainvälisiä } \\
\text { sopimuksia }\end{array}$ & & & & \\
\hline $\begin{array}{l}\text { Globaali taso } \\
\text { (WIPO ja WTO) }\end{array}$ & $\begin{array}{l}\text { Pariisin konven- } \\
\text { tio (1883), } \\
\text { Patent Coop- } \\
\text { eration Treaty } \\
\text { (PCT, 1970), } \\
\text { TRIPS (1994) }\end{array}$ & $\begin{array}{l}\text { Pariisin konven- } \\
\text { tio (1883) }\end{array}$ & $\begin{array}{l}\text { Pariisin kon- } \\
\text { ventio (1883), } \\
\text { Haagin sopimus } \\
\text { (1925), TRIPS } \\
(1994)\end{array}$ & $\begin{array}{l}\text { Pariisin konven- } \\
\text { tio (1883), } \\
\text { Madridin } \\
\text { sopimus (1891) } \\
\text { ja TRIPS (1994) }\end{array}$ \\
\hline $\begin{array}{l}\text { Alueellinen taso } \\
\text { (esimerkkinä } \\
\text { Eurooppa) }\end{array}$ & $\begin{array}{l}\text { Euroopan } \\
\text { patenttisopimus } \\
\text { (1973) }\end{array}$ & & $\begin{array}{l}\text { Neuvoston } \\
\text { asetus (EY) } \\
\text { N:o 6/2002 } \\
\text { yhteisömallista } \\
\text { ja komission } \\
\text { asetus (EY) } \\
\text { N:o 2245/2002 } \\
\text { täytäntöön- } \\
\text { panosta }\end{array}$ & $\begin{array}{l}\text { Neuvoston } \\
\text { asetus (EY) N:o } \\
\text { 207/2009 } \\
\text { Euroopan } \\
\text { unionin } \\
\text { tavaramerkistä } \\
\text { ja komission } \\
\text { asetus (EY) } \\
\text { N:o 2868/95 } \\
\text { täytäntöön- } \\
\text { panosta }\end{array}$ \\
\hline
\end{tabular}




\begin{tabular}{|c|c|c|c|c|}
\hline $\begin{array}{l}\text { Kansallinen taso } \\
\text { (Suomi) }\end{array}$ & $\begin{array}{l}\text { Patenttilaki } \\
550 / 1967 \text { ja } \\
\text { Patenttiasetus } \\
660 / 1980\end{array}$ & $\begin{array}{l}\text { Hyödyllisyys- } \\
\text { mallilaki } \\
\text { 800/1991 ja } \\
\text { Asetus hyödylli- } \\
\text { syysmallioikeu- } \\
\text { desta 1419/1991 }\end{array}$ & $\begin{array}{l}\text { Mallioikeuslaki } \\
\text { 221/1971 ja } \\
\text { Mallioikeus- } \\
\text { asetus 252/1971 }\end{array}$ & $\begin{array}{l}\text { Tavaramerkki- } \\
\text { laki 544/2019 }\end{array}$ \\
\hline $\begin{array}{l}\text { Aineettomia } \\
\text { oikeuksia } \\
\text { tutkii, } \\
\text { myöntää ja } \\
\text { rekisteröi }\end{array}$ & & & & \\
\hline Globaali taso & WIPO (PCT) & - & WIPO (Hague) & WIPO (Madrid) \\
\hline Eurooppa-taso & EPO & - & EUIPO & EUIPO \\
\hline Suomen taso & PRH & PRH & PRH & PRH \\
\hline $\begin{array}{l}\text { Valikoituja } \\
\text { tietokantojen } \\
\text { hakupalveuja }\end{array}$ & & & & \\
\hline Globaali taso & $\begin{array}{l}\text { WIPO Patent- } \\
\text { scope }\end{array}$ & $\begin{array}{l}\text { WIPO Patent- } \\
\text { scope }\end{array}$ & $\begin{array}{l}\text { WIPO Global } \\
\text { Design Database } \\
\text { ja DesignView }\end{array}$ & $\begin{array}{l}\text { WIPO Global } \\
\text { Brand Database } \\
\text { ja TMView }\end{array}$ \\
\hline Eurooppa-taso & EPO Espacenet & EPO Espacenet & EUIPO eSearch & EUIPO eSearch \\
\hline Suomen taso & PRH PatInfo & PRH PatInfo & $\begin{array}{l}\text { PRH Malli- } \\
\text { oikeustieto- } \\
\text { palvelu }\end{array}$ & $\begin{array}{l}\text { PRH Tavara- } \\
\text { merkki- } \\
\text { tietopalvelu }\end{array}$ \\
\hline
\end{tabular}

Huomioita: WIPO Lex -tietokannasta voi tarkistaa valitun maan ajantasaisen lainsäädännön sekä sen, missä kansainvälisissä aineettomiin oikeuksiin liittyvissä sopimuksissa kyseinen maa on osapuolena. Suomen osalta ks. https://wipolex.wipo. int/en/members/profile/FI (Viitattu 14.9.2021)

\section{IPR-aineistoja tutkimuskäytössä}

Taulukossa 1 listattiin valikoituja tietokantoja, joiden kautta voi suorittaa hakuja eri IPR-rekistereistä. Tässä osiossa sitä vastoin keskitytään aineistoihin, joita erityisesti tutkijoille on saatavilla. Kuka tahansa voi periaatteessa käydä keräämästä aineistot IPR-tietokannoista, mutta tutkijoille on myös saatavilla valmiiksi koottuja ja puhdistettuja sekä jossain määrin harmonisoituja tietokantoja ja kokonaisia rekisteriaineistoja. Useissa patenttivirastoissa on nykyisin tilasto- ja ekonomistitiimejä, jotka kehittävät tilastointia ja tutkimusaineistojen laatua sekä edistävät näiden aineistojen käyttöä tutkimuksissa, vaikutusarvioinneissa ja päätöksenteon tukena.

Esimerkiksi Euroopan Patenttiviraston EPO:n pääekonomistin yksikön tavoite on tuottaa korkeatasoista analyysiä informoidun politiikkakeskus- 
telun tueksi koskien patentteja, innovaatioita ja talouskasvua.7 Vastaavasti WIPO:n taloustieteen ja data-analyysin yksikkö tekee taloudellista analyysiä IPR-politiikan sekä innovaatiopolitiikan vaikutuksista ja on vastuussa aineettomien oikeuksien tilastojen keräämisestä maailmanlaajuisesti sekä niiden saattamisesta avoimesti kaikkien saataville. ${ }^{8}$ Yhdysvaltojen patenttivirasto USPTO julkaisi vuonna 2014 "Research agenda" -dokumentin, jossa todettiin, että viraston harjoittamalla taloustieteellisellä tutkimuksella on kaksi laajaa tavoitetta: 1) tuottaa objektiivisia ja dataan pohjautuvia neuvoja politiikantekijöiden päätöksenteon tueksi ja 2) lisätä ymmärrystä sekä virastossa että sen ulkopuolella aineettomien oikeuksien järjestelmän toiminnasta ja sen taloudellisista vaikutuksista mukaan lukien viraston omien toimenpiteiden vaikutukset (Graham \& Hancock 2014, s. 36). Näiden yksiköiden ohella myös IP Australialla ja Ison-Britannian IPO:lla on omat pääekonomistien johtamat tilastotiimit, joiden tehtävänkuvat ovat vastaavat.

\section{Patentti-informaatio, hyödyllisyysmallit ja patenttiperheet}

Aineistot voidaan jakaa havaintoyksikön mukaan makro- ja mikroaineistoihin. Makroaineistoilla viitataan tässä yhteydessä maatasolla aggregoituihin aineistoihin eli esim. haetut patentit Suomessa tietyllä aikavälillä, kun taas mikroaineisto viittaa aineistoihin, joissa havaintoyksikkönä on yksittäisen IPR-dokumentin tiedot, jotka voi olla aggregoituna myös esimerkiksi hakijatai keksijätasolle. Patenttidokumenteista löytyy monenlaista informaatiota kuten patentoidun keksinnön nimi, tiivistelmä, kuvaus, patenttivaatimukset, keksinnön teknologialuokitukset (esim. International Patent Classification, IPC), hakijan tai hakijoiden tiedot (ml. sijainti), keksijöiden tiedot, hakijan sekä patenttitutkijan viittauksia aiempiin patentteihin.

Yhdysvaltojen patenttiviraston USPTO:n patenttirekisteriaineistoja on käytetty oletettavasti eniten tutkimusaineistona. Yksi eniten tutkimuksissa käytetty patenttiaineistoista on Hall ym. (2001) patenttisitaattiaineisto (Jaffe \& de Rassenfosse 2017). Kyseisellä työpaperilla oli 4549 viittausta Google Scholarissa tämän artikkelin kirjoitushetkellä (19.8.2021). Yleisesti voi todeta, että yhdysvaltalaisen patenttijärjestelmän kehittämisen tueksi löytyy ylivoimaisesti eniten tutkimustietoa, mutta suuri osa tästä tutkimustiedosta on myös hyvin ristiriitaista ja päätyy erilaisiin johtopäätöksiin.

\footnotetext{
7 https://www.epo.org/about-us/services-and-activities/chief-economist.html (Viitattu 23.8.2021)

8 https://www.wipo.int/about-wipo/en/activities_by_unit/index.jsp?id=48 (Viitattu 23.8.2021)
} 
Euroopan patenttiviraston EPO:n PATSTAT (Worldwide Patent Statistical Database) on mahdollistanut monenlaiset tutkimukset, jotka ottavat Yhdysvaltoja laajemman näkökulman. PATSTAT on maailman kattavin patenttitietokanta, joka kattaa yli 130 miljoonaa patenttidokumenttia kaikista maailman maista. ${ }^{9}$ Aineiston hyödyntämisestä kiinnostuneita varten löytyy perehdytyksiä kuten de Rassenfosse ym. (2014 ja 2017), Kang ja Tarasconi (2016) ja Pasimeni (2019), jotka opastavat muun muassa, kuinka tietokannasta voi tehdä SQL-hakuja.

Näiden lisäksi löytyy myös japanilaisia ja korealaisia tietokantoja (Goto \& Motohashi 2007; Kim \& Lee 2015), joihin ei tässä yhteydessä paneuduta sen enempää. Myös Kim ja Lee (2015, taulukko 1) raportoivat, että näitä tietokantoja on hyödynnetty huomattavasti vähemmän kuin yhdysvaltalaista tai EPO:n tietokantaa tutkimuksissa, jotka on julkaistu eräissä johtavissa innovaatiotutkimuksen aikakauskirjoissa (Research Policy, Technovation, R\&D Management, Technological Forecasting and Social Change). On syytä huomata, että EPO:n PATSTAT pitää sisällään myös perustiedot japanilaisista ja korealaisista patenttidokumenteista. Edellä mainittujen lisäksi Australia on vuodesta 2014 tarjonnut avoimesti perustiedot IPR-rekistereistä (patentit, tavaramerkit, mallioikeudet, kasvinjalostajan oikeudet) viimeisen sadan vuoden ajalta csv-tiedostoina (Mitra-Kahn ym. 2016). ${ }^{10}$

Patentit ja hyödyllisyysmallit muodostavat yhdessä samaa keksintöä suojaavia patenttiperheitä. Patenttiperhe koostuu samaa keksintöä eri maissa suojaavista patenteista ja hyödyllisyysmalleista, mutta sen tekniselle määrittelylle on useita vaihtoehtoisia tapoja (esim. INPADOC- ja DOCDB-perheet, ks. Martínez 2011; Kang \& Tarasconi 2016; Heikkilä \& Verba 2018). Hyödyllisyysmallit ovat jääneet tutkimuksissa hyvin vähälle huomiolle, vaikkakin ne löytyvät esim. PATSTAT-tietokannasta. Nykyisin valtaosa maailmalla haetuista hyödyllisyysmalleista on kiinalaisia (96,9 \% vuonna 2019, WIPO 2021), kun taas Euroopassa hyödyllisyysmallijärjestelmien systemaattinen kehitys on ollut pysähdyksissä jo pidemmän aikaa (Heikkilä 2018; Heikkilä \& Verba 2018).

Maailman viisi suurinta patenttivirastoa eli Yhdysvaltojen (USPTO), Kiinan (CNIPA), Japanin (JPO), Etelä-Korean (KIPO) ja Euroopan patenttivirasto (EPO) tekevät yhteistyötä patenttijärjestelmien tehostamiseksi. Tämän ns. "IP5"-yhteistyön verkkosivujen mukaan kyseiset virastot käsittelevät n. 80 \% kaikista maailman patenttihakemuksista ja 95 \% WIPO:n PCT-järjestel-

\footnotetext{
9 https://www.epo.org/searching-for-patents/business/patstat.html (Viitattu 16.8. 2021)

10 IP Australia: Intellectual Property Government Open Data (IPGOD) -aineisto https:// data.gov.au/data/dataset/ipgod2021 (Viitattu 16.8.2021)
} 
mään liittyvästä työstä. IP5 julkaisee vuosittaisen raportin kyseisten virastojen keskeisistä tilastoista. ${ }^{11}$ IP5:1lä on ollut vuodesta 2012 alkaen käynnissä "Global Dossier" -projekti, jonka tavoitteena on koota yhteen avoimeen ja ilmaiseen tietokantaan reaaliaikaiset tiedot kyseisten virastojen patenttihakemuksista, jotka koskevat samoja keksintöjä eli ns. patenttiperheitä. ${ }^{12}$ Tietokanta julkaistiin käyttäjille vuonna 2014 ja se sisältää patenttidokumenttien tietojen ohella hakemusten käsittelyyn liittyviä tietoja (ml. uutuustutkimusraportteja, virastojen toimia, ym.).

Usein IPR-tilastoissa keskitytään vain määrään ja laatu jää vähemmälle huomiolle. Patenttien määrä on perinteinen innovaatiotoiminnan mittari (Griliches 1990; Nagaoka ym. 2010; Igami \& Subrahmanyam 2019), mutta paljon on kiinnitetty huomiota myös patenttien "laatuun", jonka mittaaminen ei ole yksiselitteistä (Higham ym. 2021). Patenttiviittaukset ovat perinteinen mittari (Hall ym. 2001; Higham ym. 2021) patenttien suojaamien keksintöjen laadulle (vrt. tutkimusjulkaisujen vaikuttavuuden mittaus viittauksilla bibliometrisessa ja skientometrisessa tutkimuksessa). Yksinkertaistetusti, mitä enemmän patenttiin viitataan, sitä merkittävämpi ja mahdollisesti arvokkaampi on patentissa kuvattu keksintö. Patenttiviittausten avulla on mahdollista tutkia teknologisen kehityksen ja innovaatiotoiminnan kumulatiivisuutta eli sitä, miten uudet ideat syntyvät aiempien päälle ja niitä yhdistelemällä. Nykyiset keksijät "seisovat aina jättiläisten olkapäillä" Isaac Newtonin ilmausta mukaillen. Jaffe \& de Rassenfosse (2017) käyvät läpi viittausten käyttöä yhteiskuntatieteellisessä tutkimuksessa. He raportoivat muun muassa, että "patent citation" -termin ilmaantuvuus Google Scholarissa listatuissa tieteellisissä julkaisuissa yli kymmenkertaistui aikavälillä 2010-2014.

\section{Tavaramerkit ja mallisuojat}

Patentit ovat saaneet aineettomien oikeuksien tutkimuksessa merkittävästi enemmän huomiota kuin tavaramerkit ja mallisuojat. Tämä on taloustieteen näkökulmasta ymmärrettävää, koska patenteissa dokumentoidaan ratkaisuja uusia teknisiin ongelmiin ja ne soveltuvat sen vuoksi yhdeksi teknologisen (myös teknisen) kehityksen mittariksi. Kaikilla suojamuodoilla on kuitenkin paikkansa esimerkiksi toimiala-analyyseissä ja toimialojen dynamiikkaa tutkittaessa. Vain huomioimalla kaikki suojamuodot ja variaatiot niiden hyödyntämisessä eri toimijoiden välillä, voidaan saada kokonaiskuvat toimialojen dynamiikasta, kilpailusta ja innovaatiotoiminnasta.

\footnotetext{
11 https://www. fiveipoffices.org/statistics/statisticsreports (Viitattu 16.8.2021)

12 https://WWW. fiveipoffices.org/activities/globaldossier (Viitattu 16.8.2021)
} 
Tavaramerkki- ja mallioikeustutkimuksen haasteena on globaalin tutkimusaineiston puuttuminen. Esimerkiksi EU-tavaramerkeistä ja yhteisömalleista vastaavan EUIPO:n rekisteriaineistot eivät ole samalla tasolla kuin EPO:n PATSTAT patenttien osalta, vaikkakin EUIPO:n yhteistyössä eurooppalaisten patenttivirastojen kanssa kehittämät tiedonhakupalvelut TMView ja DesignView ovat kehittyneet merkittävästi (Reginald \& Rea 2011). Eri puolilla maailmaa on kuitenkin tapahtunut edistysaskeleita viime aikoina. Yksi esimerkki edistysaskeleista on Petrien ym. (2020) "TM-link" -aineisto, joka yhdistää 12 miljoonaa myönnettyä tavaramerkkiä ja tavaramerkkihakemusta viideltä alueelta (Australia, Kanada, Uusi-Seelanti, Yhdysvallat ja EU). Samanaikaisesti kansallisilla tasoilla pyritään linkittämään tavaramerkkiaineistoja patenttiaineistoihin, mallioikeusaineistoja patenttiaineistoihin ja tietysti kaikkia kolmea yhteen hakijoiden perusteella (He ym. 2018; Ikeuchi \& Motohashi 2020).

Mitä paremmin laadukasta aineistoa on saatavilla, sitä nopeammin tekoälysovelluksia todennäköisesti kehitetään. Eräs mahdollinen haaste tässä kehitystyössä on tehokas työnjako julkisten toimijoiden välillä sekä julkisten ja yksityisten toimijoiden välillä. Yksityiset toimijat pyrkivät kehittämään julkisten aineistojen pohjalta ratkaisuja, mutta keskinäisen yksityisen sektorin kilpailun lisäksi niiden tarjoamiin palveluihin kohdistuu kilpailua myös julkiselta sektorilta, joka jatkuvasti parantaa tarjontaansa ja ottaa jatkuvasti käyttöön uusia sovelluksia.

Taloustieteilijät puhuvat tekoälystä uutena yleiskäyttöisenä teknologiana (esim. Trajtenberg 2018; Hyytinen 2018). Oletettavasti tekoäly tulee mullistamaan paikoitellen myös IPR-kenttää ja voi automatisoida erilaisia IPR-analyyseja päätöksenteon tueksi (Aristodemou \& Tietze 2018). Kuvanja hahmontunnistusteknologiat ovat erityisen hyvin sovellettavissa niihin tavaramerkkeihin ja malleihin, joissa suoja-alan laajuus perustuu nimenomaan kuviin. EUIPO on tarjonnut vuodesta 2015 alkaen kuvahakumahdollisuutta tietokannoistaan (käyttäjän lisäämän kuvan samankaltaisuus tietokannasta löytyviin kuviin) ja WIPO julkisti 2019 tekoälyä hyödyntävän brändien hakupalvelunsa osana Global Brand Database -tietokantaa. ${ }^{13}$

Taulukko 2 tarjoaa yhteenvedon eräistä valikoiduista IPR-aineistoista. Listaus ei ole missään nimessä kattava ja näiden aineistojen ohella tutkijat voivat kerätä tietoja suoraan tekemällä hakuja esimerkiksi Taulukossa 1 yllä listatuista tietokannoista. 
Taulukko 2. Valikoituja IPR-aineistoja.

\begin{tabular}{|c|c|c|c|c|c|c|}
\hline Aineisto & IPR & Alueellinen rajaus & Ylläpitäjä & Kuvaus & Avoimuus & Lähde \\
\hline $\begin{array}{l}\text { WIPO IP Statistics } \\
\text { Data Center }\end{array}$ & $\begin{array}{l}\text { Patentti (ml. PCT), } \\
\text { hyödyllisyysmalli, } \\
\text { tavaramerkki, mallioikeus, } \\
\text { maantieteellinen merkintä }\end{array}$ & $\begin{array}{l}\text { Lähes kaikki maail- } \\
\text { man maat (erilaisin } \\
\text { kattavuuksin) }\end{array}$ & WIPO & $\begin{array}{l}\text { Makroaineistoja. Muun muassa hakemus- ja myöntömäärät } \\
\text { vuositasolla maittain. }\end{array}$ & Avoin & $\begin{array}{l}\text { https://www3.wipo. } \\
\text { int/ipstats/index.htm }\end{array}$ \\
\hline PATSTAT & $\begin{array}{l}\text { Patentti ja hyödyllisyys- } \\
\text { malli }\end{array}$ & Globaali & EPO & $\begin{array}{l}\text { Bibliografiset tiedot johtavien teollisuusmaiden ja kehitty- } \\
\text { vien maiden kaikista patenteista ja hyödyllisyysmalleista. } \\
\text { Pohjautuu EPO:n tietokantaan. Johdatus tietokantaan: de } \\
\text { Rassenfosse ym. (2014 ja 2017). }\end{array}$ & Maksullinen & $\begin{array}{l}\text { https://www.epo.org/ } \\
\text { searching-for- } \\
\text { patents/business/ } \\
\text { patstat.html }\end{array}$ \\
\hline EPO bulk data & $\begin{array}{l}\text { Patentti ja hyödyllisyys- } \\
\text { malli }\end{array}$ & Globaali & EPO & Raakadata EPO:n patenttiaineistoista. & $\begin{array}{l}\text { Osa avoimia, osa } \\
\text { maksullisia }\end{array}$ & $\begin{array}{l}\text { https://www.epo.org/ } \\
\text { searching-for- } \\
\text { patents/data/bulk- } \\
\text { datasets.html }\end{array}$ \\
\hline EUIPO open data & Tavaramerkki, mallioikeus & EU-maat & EUIPO & $\begin{array}{l}\text { Tietoaineisto EUIPO:n EU:n tavaramerkki- ja yhteisömalli- } \\
\text { hakemuksista sekä hakijoista ja hakijoiden edustajista }\end{array}$ & Avoin & $\begin{array}{l}\text { https://euipo.europa. } \\
\text { eu/ohimportal/fi/ } \\
\text { open-data }\end{array}$ \\
\hline Global Dossier & $\begin{array}{l}\text { Patentti ja hyödyllisyys- } \\
\text { malli }\end{array}$ & $\begin{array}{l}\text { Yhdysvallat, } \\
\text { EPO-hakemukset, } \\
\text { Kiina, Japani, } \\
\text { Etelä-Korea }\end{array}$ & $\mathrm{IP}_{5}$ & $\begin{array}{l}\text { Tiedot IP5-virastojen patenttihakemuksista, jotka koskevat } \\
\text { samoja keksintöjä eli ns. patenttiperheitä. Sisältää patentti- } \\
\text { dokumenttien tietojen ohella hakemusten käsittelyyn } \\
\text { liittyviä tietoja (ml. uutuustutkimusraportteja, virastojen } \\
\text { toimia, ym.). }\end{array}$ & Avoin & $\begin{array}{l}\text { https://globaldossi- } \\
\text { er.uspto.gov/ }\end{array}$ \\
\hline $\begin{array}{l}\text { The NBER U.S. } \\
\text { Patent Citations } \\
\text { Data File }\end{array}$ & Patentti & US & $\begin{array}{l}\text { NBER (ei } \\
\text { päivitetä } \\
\text { enää) }\end{array}$ & $\begin{array}{l}\text { Yksityiskohtaiset tiedot yli kolmesta miljoonasta vuosina } \\
1963-1999 \text { myönnetystä patentista, kaikki viittaukset } \\
\text { kyseisiin patentteihin vuosilta 1975-1999 (>16 miljoonaa) } \\
\text { ja patenttien laaja linkitys Compustat-tietokantaan (kaikki } \\
\text { yhdysvaltalaisilla osakemarkkinoilla julkisesti noteeratut } \\
\text { yritykset). Tarkempi kuvaus: Hall ym. (2001). }\end{array}$ & Avoin & $\begin{array}{l}\text { https://www.nber. } \\
\text { org/research/data/ } \\
\text { us-patents }\end{array}$ \\
\hline $\begin{array}{l}\text { USPTO bulk data } \\
\text { files }\end{array}$ & $\begin{array}{l}\text { Patentti (ml. design- } \\
\text { patentti), tavaramerkki }\end{array}$ & US & USPTO & $\begin{array}{l}\text { Raakadata kaikista USPTO:n patentti (ml. designpatentti) ja } \\
\text { tavaramerkkiaineistoista. }\end{array}$ & Avoin & $\begin{array}{l}\text { https://bulkdata. } \\
\text { uspto.gov/ }\end{array}$ \\
\hline Open data portal & $\begin{array}{l}\text { Patentti (ml. design- } \\
\text { patentti), tavaramerkki }\end{array}$ & US & USPTO & $\begin{array}{l}\text { Listaus USPTO:n avoimesti saatavilla olevista aineistoista. } \\
\text { Tarkempia kuvauksia, mm. tavaramerkeistä: Graham ym. } \\
(2013,2015) \text { ja patenteista: Graham ym. (2018). }\end{array}$ & Avoin & $\begin{array}{l}\text { https://developer. } \\
\text { uspto.gov/data }\end{array}$ \\
\hline
\end{tabular}




\begin{tabular}{|c|c|c|c|c|c|c|}
\hline $\begin{array}{l}\text { Artificial Intelli- } \\
\text { gence Patent Dataset } \\
\text { (AIPD) }\end{array}$ & Patentti & US & USPTO & $\begin{array}{l}\text { 1976-2020 myönnetyt yhdysvaltalaispatentit, joissa on } \\
\text { "tekoälykomponentti" ("machine learning, natural language } \\
\text { processing, computer vision, speech, knowledge processing, } \\
\text { AI hardware, evolutionary computation, and planning and } \\
\text { control"). Tarkempi kuvaus: Giczy ym. (2021). }\end{array}$ & Avoin & $\begin{array}{l}\text { https://www. uspto. } \\
\text { gov/ip-policy/ } \\
\text { economic-research/ } \\
\text { research-datasets/ } \\
\text { artificial-intelli- } \\
\text { gence-patent-dataset }\end{array}$ \\
\hline $\begin{array}{l}\text { Chinese Patent } \\
\text { Database }\end{array}$ & $\begin{array}{l}\text { Patentti, hyödyllisyys- } \\
\text { malli, mallioikeus }\end{array}$ & Kiina & $\begin{array}{l}\text { He ym. } \\
\text { (2018) }\end{array}$ & $\begin{array}{l}\text { Kiinan patenttiviraston SIPO:n (nyk. CNIPA) patentit, } \\
\text { hyödyllisyysmallit ja mallioikeudet yhdistettynä puhdistet- } \\
\text { tuihin kiinalaisiin yritystietoihin. Tarkempi kuvaus: He } \\
\text { ym. (2018) }\end{array}$ & Avoin & $\begin{array}{l}\text { https://sites.google. } \\
\text { com/site/sipopdb/ ja } \\
\text { https://dataverse. } \\
\text { harvard.edu/data- } \\
\text { verse/cpdp }\end{array}$ \\
\hline $\begin{array}{l}\text { Intellectual Property } \\
\text { Government Open } \\
\text { Data (IPGOD) }\end{array}$ & $\begin{array}{l}\text { Patentti, tavaramerkki, } \\
\text { mallioikeus, kasvinjalosta- } \\
\text { jan oikeus }\end{array}$ & Australia & $\begin{array}{l}\text { IP Aus- } \\
\text { tralia }\end{array}$ & $\begin{array}{l}\text { Perustiedot australialaisista patenteista, innovaatiopaten- } \\
\text { teista (paikallinen "pikkupatentti” tai hyödyllisyysmallin } \\
\text { kaltainen suojamuoto), tavaramerkeistä, mallioikeuksista } \\
\text { sekä kasvinjalostajan oikeuksista sekä tietoja hakemispros- } \\
\text { esseista. Tarkempi kuvaus: Mitra-Kahn ym. (2016). }\end{array}$ & Avoin & $\begin{array}{l}\text { https://data.gov. } \\
\text { au/data/dataset/ip- } \\
\text { god2021 }\end{array}$ \\
\hline TM-Link & Tavaramerkki & Australia & $\begin{array}{l}\text { IP Aus- } \\
\text { tralia }\end{array}$ & $\begin{array}{l}\text { "TM-link"-aineisto, joka yhdistää } 12 \text { miljoonaa myönnettyä } \\
\text { tavaramerkkiä ja tavaramerkkihakemusta viideltä alueelta } \\
\text { (Australia, Kanada, Uusi-Seelanti, Yhdysvallat ja EU). } \\
\text { Tarkempi kuvaus: Petrie ym. (2020) }\end{array}$ & Avoin & $\begin{array}{l}\text { https://www.tmlink. } \\
\text { net.au/ }\end{array}$ \\
\hline IIP Patent Database & Patentti & Japani & $\begin{array}{l}\text { The } \\
\text { Institute of } \\
\text { Intellectual } \\
\text { Property } \\
\text { (IIP) }\end{array}$ & $\begin{array}{l}\text { Japanilaisten patenttien tietokanta tutkimuskäyttöön. } \\
\text { Tarkempi kuvaus: Goto \& Motohashi (2007) }\end{array}$ & $\begin{array}{l}\text { Vaatii rekisteröity- } \\
\text { misen }\end{array}$ & $\begin{array}{l}\text { https://www.iip. } \\
\text { or.jp/e/patentdb/ } \\
\text { index.html }\end{array}$ \\
\hline
\end{tabular}

Huomioita: Lista ei ole kattava. Mukana ei ole mm. kaupallisten tahojen tarjoamia palveluita (ks. Housh 1998). Myös WIPO on listannut aineistoja sivulla https://www.wipo.int/econ_stat/en/economics/research/. On syytä mainita, että monien listattujen aineistojen välillä on huomattavasti päällekkäisyyttä. 


\section{IPR-aineistojen mahdollisuuksia, tutkimusten replikointia ja rajoitteita}

Aiemmissa luvuissa tehtiin tiivis katsaus aineettomien oikeuksien aineistoihin. Nämä aineistot mahdollistavat erilaisten hypoteesien testaamisen ja vaikutusarvioinnit IPR-järjestelmien kontekstissa. Digitalisaation myötä aineistojen saatavuus tutkimuskäyttöön on parantunut ja aineistoja voidaan kasvavassa määrin hyödyntää instituutioiden kehittämisessä ja politiikantekijöiden päätöksenteon tukena.

Seuraavaksi käyn läpi valikoituja mielenkiintoisia jatkotutkimusaiheita, nostan esiin aiempien tutkimusten replikoinnin tärkeyden sekä kertaan muutamia toistuvia teknisiä haasteita ja rajoituksia IPR-aineistojen hyödyntämisessä.

\section{Jatkotutkimusaiheita}

Eräs nopea tapa tarkastella mielenkiintoisia aineettomien oikeuksien tutkimuksessa pinnalla olevia aiheita on hakea artikkeleita alan johtavissa aikakauskirjoissa (mm. Research Policy, World Patent Information tai Scientometrics) hakusanoilla "patent", "trademark" tai "design right". Tämän ohella voi käydä tarkistamassa, mitkä uudet artikkelit ja työpaperit viittaavat aihepiirin keskeisimpiin julkaisuihin (esim. patenttien osalta Hall ym. 2001). Lisäksi alan konferensseissa (esim. European Policy for Intellectual Property, EPIP) esitetään alan tutkimuksen eturintaman uusia tuulia. Seuraavaksi listaan eräitä mielenkiintoisia jatkotutkimusaiheita. ${ }^{14}$

\section{Muut suojamuodot kuin patentit}

Patenttiaineistoja on analysoitu tieteellisesti huomattavasti enemmän kuin muiden aineettomien oikeuksien tilastoja. Yksi keskeinen syy tähän on kattavien tavaramerkki- ja mallioikeusaineistojen saatavuuden puute. Lisäksi kansalliset erot järjestelmissä tekevät kansainvälisistä vertailuista haastavia. Muiden suojamuotojen kuin patenttien tilastollista tutkimusta edistäisivät tutkijoille tarjotut puhdistetut aineistot. Tutkijayhteisö hyötyisi globaalista

14 Näiden aiheiden ohella patenttien ja muiden IPR:ien arvonmääritys on aina pinnalla. Mm. Kapoor ym. (2013) käyvät läpi patenttien arvoindikaattoreita ja Takalo ym. (2021) tarjoavat katsauksen suomalaisten patenttien arvon määrittely kansantalouden näkökulmasta. COVID-19 myötä lääkkeiden patentoinnin tutkimus on saanut lisähuomiota ja tälläkin saralla tehdään korkealaatuista suomalaista tutkimusta patenttiaineistoilla (ks. esim. Izhak ym. 2020; Kinnunen ym. 2021). 
tavaramerkkien ja mallioikeuksien omasta "PATSTAT"-aineistosta, joka jo löytyy patenteille. Tämä mahdollistaisi muun muassa sen tutkimisen, eroavatko tavaramerkkien ja mallioikeuksien kansainväliset suojausstrategiat patenttien vastaavasti. Kokonaisvaltainen IPR-näkökulma ottaa huomioon kaikki nämä erilaiset teollisoikeudet ja voi - luonnollisesti tutkimuskysymyksistä riippuen - tarjota paremman kokonaiskuvan tutkimuskysymyksiin muun muassa toimialojen dynamiikkaa, kilpailua ja innovaatiotoimintaa tutkittaessa.

\section{Euroopan integraatio}

Suomessa ja Euroopassa Euroopan integraation seurauksena painopiste on siirtynyt yli ajan kansallisilta viranomaisilta eurooppalaisille viranomaisille (Patentit ja EPO: Hall \& Helmers 2019; Tavaramerkit: Herz \& Mejer 2019). Empiirisessä tutkimuskirjallisuudessa haaste Suomen kaltaisen pienen avoimen talouden näkökulmasta on se, että suuri osa analyyseista ja tutkimuksista kohdistuu suurten maiden, erityisesti Yhdysvaltojen, IPR-järjestelmiin ja niistä saatuja tuloksia ei välttämättä voi yleistää suomalaiseen ja eurooppalaiseen institutionaaliseen kontekstiin. Viime aikoina Brexitillä on ollut oma vaikutuksensa. Kuinka ja millä tahdilla Euroopan integraatio etenee IPRkentällä? Saako Eurooppa 2020-luvulla yhtenäispatenttijärjestelmän ja yhdistetyn patenttituomioistuimen? Minkälaisia vaikutuksia ne toteutuessaan aiheuttavat?

\section{Kiinan roolin kasvu}

IPR-hakemusmäärät ovat kasvaneet valtavasti Kiinan patenttivirastolla (CNIPA) 2000-luvulla ja Kiina on muun muassa ohittanut Yhdysvallat vuosittaisissa patenttihakemusmäärissä (WIPO 2021). Kiinan hakemusmääriin ja haettujen patenttien laatuun ovat vaikuttaneet myös julkiset tuet patenttien hakemiseen (Dang \& Motohashi 2015). Taittuuko kiinalaisten IPR-hakemusten kasvu, kun julkisia tukia vähennetään? Kaikista maailman hyödyllisyysmallihakemuksista 96,9 \% (2268190 kpl, WIPO 2021) tehtiin Kiinassa vuonna 2019. Minkälainen on kiinalaisen hyödyllisyysmallijärjestelmän tulevaisuus?

\section{Tekoäly, digitalisaatio ja automatisointi}

Tekoälyn kehitys vaikuttaa merkittävästi IPR-kenttään. Ensinnäkin, tekoälykeksintöjä on patentoitu kasvavassa määrin (WIPO 2019; Giczy ym. 
2021). Toiseksi, tekoälyn avulla kyetään automatisoimaan IPR-analytiikkaa ja tehostamaan IPR-hakuja tietokannoista (Aristodemou \& Tietze 2018). Kolmanneksi, tällä hetkellä patenttivirastoissa pohditaan, voiko tekoälyn nimetä keksijäksi patenteissa. Tätä kirjoittaessa Etelä-Afrikassa on vastikään myönnetty maailman kaikkien aikojen ensimmäinen patentti, jossa tekoäly on keksijänä. ${ }^{15}$ Kyseinen myöntöpäätös on kuitenkin valitusprosessissa.

Laadukkaan koneluettavan IPR-datan saatavuus yhdistettynä jatkuvasti kasvavaan laskentatehoon mahdollistavat erilaiset tekoälysovellukset ja automatisoidun analytiikan päätöksenteon tueksi (Aristodemou \& Tietze 2018). Näin on myös aineettomien oikeuksien kontekstissa: Mitä parempilaatuisina ja kattavampina IPR-rekisteriaineistot ovat avoimesti saatavilla, sitä todennäköisempää on, että joku niiden hyödyntäjä kehittää uusia sovelluksia ja aihepiirin tutkijat pystyvät analysoimaan IPR-instituutioiden toimintaa, testaamaan hypoteeseja ja tunnistamaan säännönmukaisuuksia. Patenttihakuja ja kilpailijaseurantaa kyetään myös yhä tehokkaammin personoimaan ja automatisoimaan tarpeiden mukaan.

Tekniikan kieli on elänyt ajassa ja niin myös kieli, jolla keksinnöt kuvataan patenttidokumenteissa. Nykyisin tekoälyn ja automaattisten käännösohjelmistojen aikakaudella tekniikan kielellä alkaa olla vähemmän merkitystä kuin aiemmin. Toisaalta suoja-alan laajuus tulkitaan edelleen sanatarkasti patenttivaatimuksista patenttiloukkaustapauksissa. Toisaalta myös yhä suurempi osa patenteista on kiinankielisiä. Maailman viisi suurinta patenttivirastoa eli IP5 seuraavat, tutkivat ja jakavat tietoa tekoälyn vaikutuksista patenttijärjestelmiin sekä kehittävät omia tekoälyratkaisujaan. ${ }^{16}$ Kuinka tekoäly tulee vaikuttamaan aineettomiin oikeuksiin liittyvän tiedonhaun automatisointiin? Minkälaisia personoituja ja yhä tarkempia suosittelualgoritmeja tulemme näkemään?

\section{Oikeustapausten linkitys IPR-rekistereihin}

Joskus aineettomiin oikeuksiin liittyvät riidat johtavat kariutuneiden neuvotteluiden jälkeen oikeudenkäynteihin. Tiedot suomalaisista oikeudenkäynneistä löytyvät tuomioistuinten arkistoista, mutta ainakin vanhemmissa tapauksissa vielä paperimuodossa digitoidun tiedon sijaan. Tutkijoiden käyttöön ei löydy ajantasaista avointa tietokantaa, joka yhdistäisi aineettomat oikeudet ja niihin

15 Patentti ZA2021/03242 "Food container and devices and methods for attracting enhanced attention", julkaisun keksijä-kentässä lukee ”DABUS, The invention was autonomously generated by an artificial intelligence". Myönnetty 24.6.2021. https://WwW. fiveipoffices.org/activities/NET_AI (Viitattu 16.8.2021) 
liittyvät oikeudenkäynnit sekä oikeuskäytännön (vrt. Kapoor 2017; Heikkilä \& Peltoniemi 2019).

IPR University Centerin Oikeustapaustietokanta ${ }^{17}$ sisältää tiivistelmiä ja skannattuja dokumentteja suomalaisten tuomioistuinten aineettomia oikeuksia koskevista ratkaisuista vuodesta 1979 lähtien, mutta tietokanta ei ole kaikenkattava. Lisäksi tietokannassa on myös työsuhdekeksintölautakunnan ratkaisujen sekä tekijänoikeusneuvoston lausuntojen tiivistelmiä. Kaupallisia palveluntarjoajia löytyy luonnollisesti, mutta niitä ei käydä läpi tässä yhteydessä (vrt. Talvela \& Kässi 2019). EUIPO:lla on oma tietokanta "eSearch Case Law", josta löytyvien kansallisten oikeustapausten määrä on kuitenkin vielä rajallinen. Yhdysvaltojen osalta patenttioikeudenkäynneistä on rakennettu tietokanta tutkijoiden käyttöön (Marco ym. 2017). WIPO Lex on verkossa avoimesti saatavilla oleva tietokanta, jossa WIPO:n mukaan on kaikkein kattavin kokoelma aineettomien oikeuksien lakeja ja kansainvälisiä sopimuksia. $^{18}$

\section{Keksijöiden moninaisuus}

Keksijöiden ja muotoilijoiden taustojen moninaisuus on tärkeä aihe tutkia, koska yksilöt ovat taipuvaisia kehittämään ratkaisuja omiin tarpeisiin (vrt. Koning ym. 2021). Naisten osuutta keksijöistä on tutkittu kasvavassa määrin yhdistelemällä sukupuolen mukaan eroteltuja nimiaineistoja patenttiaineistojen keksijätietoihin ja analyyseissa on havaittu, että naisten osuus keksijöistä on kasvanut yli ajan vaikkakin hitaasti (Lax Martínez ym. 2016, 2021; Heikkilä 2019; Pajari \& Heikkilä 2021). On myös mielenkiintoista seurata, tulemmeko pidemmällä aikavälillä näkemään IPR-rekistereissä ihmiskeksijöiden ja -muotoilijoiden ohella kasvavassa määrin tekoälyn keksijänä.

\section{Vihreät teknologiat ja kestävä kehitys}

Ilmastonmuutos on saanut kasvavassa määrin huomiota myös IPR-kentällä ja uusia menetelmiä sekä patenttiluokituksia on kehitetty tunnistamaan "vihreitä" keksintöjä ja innovaatioita sekä ympäristöystävällisiä teknologioita patenttiaineistojen avulla (mm. WIPO:n IPC Green Inventory -luokitus ${ }^{19}$; OECD:n ympäristöteknologialuokitus, ks. Haščič \& Migotto 2015). Tutkijat ovat myös koneoppimismenetelmiä hyödyntämällä pyrkineet luokittelemaan

\footnotetext{
17 https://ipruc.fi/tietopalvelut/oikeustapaustietokanta/ (Viitattu 16.8.2021)

18 https://www.wipo.int/wipolex/en/index.html (Viitattu 20.8.2021)

19 https://WwW.wipo.int/classifications/ipc/green-inventory/home (Viitattu 20.8.2021)
} 
patentteja sen mukaan, kuinka relevantteja ne ovat YK:n kestävän kehityksen tavoitteiden kannalta (esim. Suominen \& Hajikhani 2021).

\section{IPR-tutkimusten replikointi}

Maailma muuttuu, teknologia kehittyy ja IPR-instituutiot (ml. lainsäädäntö) kehittyvät ajassa, mistä syystä aiemmat empiiriset tutkimustulokset eivät välttämättä enää kuvaa muuttunutta nyky-ympäristöä ja menneisyyden havainnot eivät ole enää välttämättä yleistettävissä nykykontekstiin. Esimerkiksi aika ennen digitalisaatiota ja Internetiä 90-luvun alkupuolella oli aika tavalla erilainen toimintaympäristö verrattuna ICT-vallankumouksen jälkeiseen 2020-lukuun. Lisäksi suuri osa patenttijärjestelmien tutkimuksista on toteutettu yhdysvaltalaisilla aineistoilla ja tulosten yleistäminen esimerkiksi Suomen kaltaisen pienen avoimen talouden ja EU:n sisämarkkinan institutionaaliseen kontekstiin ei välttämättä ole suoraviivaista.

Uudet ja laajemmat tutkimusaineistot mahdollistavat aineettomiin oikeuksiin liittyvien uusien hypoteesien testaamisen sekä aiempien tutkimusten toistamisen. Samalla tutkimusten replikointi laadukkaammilla aineistoilla edistäisi tutkimukseen perustuvaa päätöksentekoa ja IPR-järjestelmien jatkokehitystyötä. Olisikin tärkeää, että uusien tutkimusideoiden kehittämisen ohella tutkijoilla olisi kannustimia replikoida aiempia tutkimuksia uusilla aineistoilla ja koetella niiden havaintoja (Hyytinen 2013; Gertler ym. 2018).

\section{Rajoituksia ja teknisiä haasteita}

Patentti- ja IPR-aineistojen hyödyntämiseen tutkimuksissa liittyy ilmeisiä ongelmia ja haasteita (esim. Griliches 1990; Motohashi ym. 2010; Igami \& Subrahmanyam 2019), joista tässä nostetaan esiin vain muutama.

Ensinnäkin, patentit ovat epätarkka innovaatiotoiminnan mittari (Griliches 1990; Nagaoka ym. 2010; Igami \& Subrahmanyam 2019). Kaikille teknisille keksinnöille ei haeta patentteja vaan vain osalle. Osa keksijöistä tai yrityksistä, joissa keksijät työskentelevät, ei edes yritä suojata keksintöjään patenteilla. Lisäksi osa keksinnöistä ei ole patentoitavissa. Innovaatiotoiminnan tutkimuksen laajentaminen patenttiaineistoista kattavampiin tavaramerkki- ja mallioikeusaineistoihin on perusteltua, mutta näitä yhdistettyjä IPR-rekisteriaineistoja ei vielä ole laajasti tutkijoiden saatavilla.

Toiseksi, keksijöiden tutkimusta rajoittaa aineiston henkilötietoluonteesta johtuen tietosuoja-asetukset ja lait. Julkisista rekistereistä löytyvistä patentti- ja muista IPR-dokumenteista löytyy keksijän nimi, joka periaatteessa mahdollistaa keksijöiden identifioinnin sekä IPR-aineiston linkityksen muihin 
tietokantoihin, joista nimitieto löytyy. IPR-aineistojen yhdistäminen muihin mikroaineistoihin tarjoaa mahdollisuuden aivan uudenlaisiin tutkimuksiin ja hypoteesien testaamiseen, mutta aineistojen käsittelyssä on turvattava henkilöiden tietosuoja. Esimerkiksi Tilastokeskuksella on asianmukaiset tietosuojaperiaatteet henkilötietojen turvaamiseen. ${ }^{20}$ Patenttiaineistojen yhdistäminen Tilastokeskuksen FLEED-mikroaineistoon ("Finnish linked employer-employee data", nyk. FOLK) eli suomalaiseen työnantaja-työntekijärekisteriaineistoon on mahdollistanut monia suomalaisia taloustieteen väitöskirjoja (esim. Väänänen 2010; Rahko 2016) ja poikkeuksellisia tutkimuksia (mm. Toivanen ja Väänänen 2012; Ejermo \& Toivanen 2018; Aghion ym. 2018). Vastaavia rekisteriaineistoja löytyy myös muista Pohjoismaista ja muun muassa Tanskassa on yhdistetty mallioikeusaineisto paikalliseen LEED-aineistoon (Fjællegaard ym. 2019).

Kolmanneksi nimien harmonisointi ja tietokantojen yhdistäminen ovat empiiristen IPR-tutkijoiden murheenkryynejä (Hall ym. 2001; Raffo \& Llhuillery 2009; Thoma ym. 2010). Kaikki nykyisiä IPR-rekistereitä käsitelleet tietävät, että tilastollisessa analyysissä yksi suurimmista haasteista on harmonisoimattomat aineettomien oikeuksien hakijoiden, haltijoiden ja keksijöiden nimet kirjoitusvirheineen kaikkineen (puhumattakaan emo- ja tytäryhtiöiden linkittämisestä). Esimerkiksi PATSTAT-tietokannasta löytyy vaihtoehtoisia yksilöiviä tunnisteita keksijöille ja yrityksille, mutta näiden PATSTAT-tietokannalle uniikkien tunnisteiden linkittäminen muihin tietokantoihin on sitten oma tekninen haasteensa.

\section{Kiitokset}

Kiitän Mikael Laaksoa ja anonyymiä lausunnonantajaa kommenteista sekä Anja ja Jalo Paanasen rahastoa (Suomen kulttuurirahasto, Päijät-Hämeen rahasto) taloudellisesta tuesta. 


\section{Lähteet}

Aghion, P. Akcigit, U., Hyytinen, A., \& Toivanen, O. (2018). On the Returns to Invention within Firms: Evidence from Finland. AEA Papers and Proceedings, 108, 208-212. https://doi. org/10.1257/pandp. 20181108

Aristodemou, L., \& Tietze, F. (2018). The state-of-the-art on Intellectual Property Analytics (IPA): A literature review on artificial intelligence, machine learning and deep learning methods for analysing intellectual property (IP) data. World Patent Information, 55, 37-51. https://doi. org/10.1016/j.wpi.2018.07.002

Bloom, N., Van Reenen, J., \& Williams, H. (2019). A Toolkit of Policies to Promote Innovation. Journal of Economic Perspectives, 33(3), 163-84. https://doi.org/10.1257/jep.33.3.163

Castaldi, C. (2020). All the great things you can do with trademark data: Taking stock and looking ahead. Strategic Organization, 18(3), 472-484. https://doi.org/10.1177/1476127019847835

Comino, S., Galasso, A., \& Graziano, C. (2020). Market Power and Patent Strategies: Evidence from Renaissance Venice. Journal of Industrial Economics, 68(2), 226-269. https://doi. org/10.1111/joie. 12223

Dang, J., \& Motohashi, K. (2015). Patent statistics: a good indicator for innovation in China? Patent subsidy program impacts on patent quality. China Economic Review, 35, 137-155. https://doi.org/10.1016/j.chieco.2015.03.012

de Rassenfosse, G., Kracker, M., \& Tarasconi, G. (2017). Getting started with PATSTAT register. The Australian Economic Review, 5O(1), 110-120. https ://doi .org/10.1111/1467-8462.12214

de Rassenfosse, G., Dernis, H., \& Boedt, G. (2014). An introduction to the PATSTAT database with example queries. The Australian Economic Review, 47(3), 395-408. https://doi. org/10.1111/1467-8462.12073

Ejermo, O., \& Toivanen, H. (2018). University invention and the abolishment of the professor's privilege in Finland. Research Policy, 47, 814-825. https://doi.org/10.1016/j. respol.2018.03.001

Euroopan Komissio (2020). Evaluation of EU legislation on design protection \{SWD(2020) 264 final\}. Bryssel, 6.11.2020.

Flikkema, M., de Man, A., \& Castaldi, C. (2014). Are trademark counts a valid indicator of innovation? Results of an in-depth study of new Benelux trademarks filed by SMEs. Industry and Innovation, 21(4), 310-331. https://doi.org/10.1080/13662716.2014.934547

Fjællegaard, C., Beukel, K., \& Alkærsig, L. (2019). Designers as the determinants of design innovations. Creativity and Innovation Management, 28(2), 144-156. https://doi.org/10.1111/ caim. 12302

Gertler, P., Galiani, S., \& Romero, M. (2018). How to make replication the norm. Nature, 554, 417-419. https://doi.org/10.1038/d41586-018-02108-9

Giczy, A., Pairolero, N., \& Toole, A. (2021). Identifying artificial intelligence (AI) invention: A novel AI patent dataset. USPTO Economic Working Paper Series, No. 2021-2. http://dx. doi.org/10.2139/ssrn. 3866793

Goto, A., \& Motohashi, K. (2007). Construction of a Japanese Patent Database and a first look at Japanese patenting activities. Research Policy, 36, 1431-1442. https://doi.org/10.1016/j. respol.2007.06.005 
Graham, S., \& Hancock, G. (2014). The USPTO economics research agenda. Journal of Technology Transfer, 39, 335-344. https://doi.org/10.1007/s10961-013-9299-6

Graham, S., Marco, A., \& Miller, R. (2018). The USPTO patent examination research dataset - a window on patent processing. Journal of Economics \& Management Strategy, 27(3), 554578. https://doi.org/10.1111/jems.12263

Graham, S., Hancock, G., Marco, A., \& Myers, A. (2013). The USPTO trademark case files dataset: Descriptions, lessons, and insights. Journal of Economics \& Management Strategy, 22(4), 669-705. https://doi.org/10.1111/jems.12035

Graham, S., Marco, A., \& Myers, A. (2015). Monetizing Marks: Insights from the USPTO Trademark Assignment Dataset. Journal of Economics and Management Strategy, 27(3), 403342. https://doi.org/10.1111/jems.12261

Griliches, Z. (1990). Patent Statistics as Economic Indicators: A Survey. Journal of Economic Literature, 28(4), 1661-1707. https://www.jstor.org/stable/2727442

Haarmann, P. (2014). Immateriaalioikeus. Talentum.

Hajikhani, A., \& Suominen, A. (2021). The Interrelation of Sustainable Development Goals in Publications and Patents: A Machine Learning Approach. 1st Workshop on AI + Informetrics - AII 2021.

Hall, B. H., Jaffe, A. B., \& Trajtenberg, M. (2001). The NBER patent citations data file: lessons, insights and methodological tools. NBER Working Paper Series, 8498. https:// doi.org/10.3386/w8498

Haščič, I., \& Migotto, M. (2015). Measuring environmental innovation using patent data. OECD Environment Working Papers, 89. https://doi.org/10.1787/5js009kf48xw-en

He, X., Tong, T., Zhang, Y., \& He, W. (2018). Constructing a Chinese Patent Database of listed firms in China: Descriptions, lessons, and insights. Journal of Economics and Management Strategy, 27(3), 579-606. https://doi.org/10.1111/jems.12186

Heikkilä, J. (2018). Empirical Analyses of European Intellectual Property Rights Institutions [Väitöskirja, Jyväskylän yliopiston kauppakorkeakoulu]. Jyväskylä Studies in Business and Economics 185. http://urn.fi/URN: ISBN: 978-951-39-7374-2

Heikkilä, J. (2019). IPR gender gaps: a first look at utility model, design right and trademark filings. Scientometrics, 118, 869-883. https ://doi.org/10.1007/s11192-018-2979-0

Heikkilä, J., \& Peltoniemi, M. (2019). Great expectations: Learning the boundaries of design rights. Research Policy, 48(9), 103795. https://doi.org/10.1016/j. respol.2019.05.004

Heikkilä, J., \& Verba, M. (2018). The role of utility models in patent filing strategies: evidence from European countries. Scientometrics, 116, 689-719. https://doi.org/10.1007/s11192018-2773-z

Herz, B., \& Mejer, M. (2019). Effects of the European Union trademark: Lessons for the harmonization of intellectual property systems. Research Policy, 48(7), 1841-1854. https://doi. org/10.1016/j.respol.2019.04.010

Higham, K., de Rassenfosse, G., \& Jaffe, A. (2021). Patent Quality: Towards a Systematic Framework for Analysis and Measurement. Research Policy, 5O(4), 104215. https://doi. org/10.1016/j.respol.2021.104215

Housh, R. (1998). Patenttitietokannat. VTT Tietopalvelut, VTT Tiedotteita - Meddelanden - Research Notes 1917. http://www.vtt.fi/inf/pdf/tiedotteet/1998/T1917.pdf 
Hyytinen, A. (2013). Väärä tulos. Kansantaloudellinen aikakauskirja, 109(3), 271-274.

Hyytinen, A. (2018). Tekoäly yleiskäyttöisenä teknologiana ja taloustieteellisen tutkimuksen välineenä. Kansantaloudellinen aikakauskirja, 114(4), 419-494.

Igami, M., \& Subrahmanyam, J. (2019). Patent statistics as an innovation indicator? Evidence from the hard disk drive industry. The Japanese Economic Review, 70(3), 308-330. https:// doi.org/10.1111/jere. 12234

Ikeuchi, K., \& Motohashi, K. (2020). Linkage of Patent and Design Right Data: Analysis of Industrial Design Activities in Companies at the Creator Level. RIETI Discussion Paper Series, 20-E-005. https://www.rieti.go.jp/jp/publications/dp/20e005.pdf

Izhak, O., Saxell, T., \& Takalo, T. (2020). Optimal Patent Policy for Pharmaceutical Industry. VATT Institute for Economic Research Working Papers, 131. https://urn.fi/URN: ISBN: 978-952-274-253-7

Jaffe, A., \& de Rassenfosse, G. (2017). Patent citation data in social science research: Overview and best practices. Journal of the Association for Information Science and Technology, 68(6), 1360-1374. https://doi.org/10.1002/asi.23731

Kang, B., \& Tarasconi, G. (2016). PATSTAT revisited - suggestions for better usage. World Patent Information, 46, 56-63. https://doi.org/10.1016/j.wpi.2016.06.001

Kapoor, R. (2017). Competition and disputes in patent lifecycle [Väitöskirja, Lappeenranta University of Technology]. http://urn.fi/URN: ISBN: 978-952-335-087-8

Kapoor, R., Karvonen, M., \& Kässi, T. (2013). Patent value indicators as proxy for commercial value of inventions. International Journal of Intellectual Property Management, 6(3), 217-232. https://doi.org/10.1504/IJIPM. 2013.056242

Kim, J., \& Lee, S. (2015). Patent databases for innovation studies - a comprehensive analysis of USPTO, EPO, JPO and KIPO. Technological Forecasting \& Social Change, 92, 332-345. https://doi.org/10.1016/j.techfore.2015.01.009

Kinnunen, M., Laukkonen, M., Linnosmaa, I., Mäklin, S., Nokso-Koivisto, O., Saxell, T., . . \& \& Valmari, N. (2021). Mikä lääkkeissä maksaa? Selvitys lääkkeiden hintaan vaikuttamisesta ja ohjauksesta. Valtioneuvoston selvitys- ja tutkimustoiminnan julkaisusarja 2021:19. http:// urn.fi/URN: ISBN: 978-952-383-194-0

Kollmann, T., Koswatta, A., Palangkaraya, A., \& Webster, E. (2020). The Impact of Design Rights on Australian Firms. IP Australia Economic Research Paper 09.

Koning, R., Samila, S., \& Ferguson, P. (2021). Who do we invent for? Patents by women focus more on women's health, but few women get to invent. Science, 372(6548), 1345-1348. https:// doi.org/10.1126/science. aba6990

Laisi, H. (2009). 75 vuotta teollisoikeudellista yhdistystoimintaa Suomessa. IPR University Centerin julkaisuja.

Lax Martínez, G., Saenz de Juano-i-Ribes, H., Yin, D., Le Feuvre, B., Hamdan-Livramento, I., Saito, K., \& Raffo, J. (2021). Expanding the World Gender-Name Dictionary: WGND 2.o. WIPO Economic Research Working Paper No. 64. http://dx.doi.org/10.34667/tind.43980

Marco, A. Tesfayesus, A., \& Toole, A. (2017). Patent Litigation Data from US District Court Electronic Records (1963-2015). USPTO Economic Working Paper No. 2017-06. http://dx.doi. org/10.2139/ssrn. 2942295 
Martínez, C. (2011). Patent families: When do different definitions really matter? Scientometrics, 86, 39-63. https://doi.org/10.1007/s11192-010-0251-3

Mitra-Kahn, B., Johnson, M., Man, B., \& Meehan, L. (2016). Intellectual Property Government Open Data: Australian Business Number Links to All Intellectual Property Data in Australia. The Australian Economic Review, 49(1), 96-104. https://doi.org/10.1111/1467-8462.12147

Nagaoka, S., Motohashi, K., \& Goto, A. (2010). Patent statistics as an innovation indicator. Teoksessa B. H. Hall \& N. Rosenberg (toim.), Handbook of the Economics of Innovation (Vol. 2, pp. 1083-1127). Elsevier. https://doi.org/10.1016/S0169-7218(10)02009-5

Oker-Blom, M. (2021). IPR-strategian taustaselvitys. IPRinfo 2/2021. https://iprinfo.fi/artikkeli/ipr-strategian-taustaselvitys/

Pajari, I., \& Heikkilä, J. (2021). Gender of patent inventors: Some highlights of recent research. IPRinfo 2/2021. https://iprinfo.fi/artikkeli/gender-of-patent-inventors-some-highlightsof-recent-research/

Pasimeni, F. (2019). SQL query to increase data accuracy and completeness in PATSTAT. World Patent Information, 57, 1-7. https://doi.org/10.1016/j.wpi.2019.02.001

Petrie, S., Adams, M., Mitra-Kahn, B., Johnson, M., Thomson, R., Jensen, P., . . Webster, E. (2020). TM-Link: An Internationally Linked Trademark Database. The Australian Economic Review, 53(2), 254-269. https://doi.org/10.1111/1467-8462.12373

Raffo, J., \& Llhuillery, S. (2009). How to play the "Names Game": Patent retrieval comparing different heuristics. Research Policy, 38(10), 1617-1627. https://doi.org/10.1016/j. respol. 2009.08.001

Rahko, J. (2016). Essays on R\&D, knowledge spillovers and firm performance [Väitöskirja, Vaasan yliopisto]. Acta Wasaensia 357. http://urn.fi/URN: ISBN: 978-952-476-699-9

Reginald, D., \& Rea, M. (2011). Taking a wider view of trade marks and the TMview database. World Patent Information, 33, 389-392. https://doi.org/10.1016/j.wpi.2011.07.006

Roser, M. (2013). Economic Growth. OurWorldInData.org. Saatavilla verkossa: https:// ourworldindata.org/economic-growth

Salminen, V., Halme, K., Kettinen, J., Härmälä, V., Järvelin, A., Suominen, A., . . S Stevenson, A. (2021). Aineettomien oikeuksien tilanne Suomessa 2020: IPR-strategian taustoitus. Valtioneuvoston selvitys- ja tutkimustoiminnan julkaisusarja 2021:13. http://urn.fi/ URN : ISBN: 978-952-383-089-9

Takalo, T., Hyytinen, A., \& Stevenson, A. (2021). Teollisoikeuksien kansantaloudellinen merkitys ja arvon märittely. Valtioneuvoston selvitys- ja tutkimustoiminnan julkaisusarja 2021:13. http://urn.fi/URN: ISBN: 978-952-383-089-9

Talvela, J., \& Kässi, T. (2019). Patent litigation by private inventors - case Finland. Teoksessa Proceedings of 1oth European Conference on Intangibles and Intellectual Capital. University of Chieti-Pescara.

Thoma, G., Torrisi, S., Gambardella, A. Guellec, D., Hall, B., \& Harhoff, D. (2010). Harmonising and Combining Large Datasets - An Application to Firm-Level Patent and Accounting Data. NBER Working Paper 15851. http://www. nber.org/papers/w15851.pdf

Trajtenberg, M. (2018). AI as the next GPT: a Political-Economy Perspective. NBER Working Paper 24245. https://doi.org/10.3386/w24245 
Toivanen, O., \& Väänänen, L. (2012). Returns to inventors. Review of Economics and Statistics, 94(4), 1173-1190. https://doi.org/10.1162/REST_a_00269

Väänänen, L. (2010). Human capital and incentives in the creation of inventions: A study of Finnish inventors [Väitöskirja, Aalto University School of Business and Economics]. http:// urn.fi/URN: ISBN: 978-952-60-1031-1

WIPO (2019). Artificial intelligence. WIPO Technology Trends 2019. https://www.wipo.int/publications/en/details.jsp?id=4386

WIPO (2021). World Intellectual Property Indicators 2020. http://dx.doi.org/10.34667/ tind. 42184 